\title{
HUMANISTINIO DVASINGUMO RYŠYS SU AUKLE்JIMO ŠEIMOJE PATIRTIMIS
}

\author{
Simona Kontrimienè \\ Vilniaus universitetas
}

\begin{abstract}
Anotacija
Straipsnyje pristatomu tyrimu $(N=514)$ siekiama nustatyti sąsajas tarp humanistinio dvasingumo, kaip jis konceptualizuojamas mūsų sukurtame Humanistinio dvasingumo modelyje, ir auklèjimo šeimoje patirčių - autoritetingojo, valdingojo bei leidžiančiojo auklëjimo šeimoje stilių, tèvų psichologinès ir elgesio kontrolès bei saugaus ir nesaugaus prieraišumo prie tèvų ir prie Kito suaugystejje stilių. Tyrimo nustatyta, kad iš trijų auklëjimo šeimoje stilių tik autoritetingasis yra svarbus teigiamas dvasingumo prediktorius, tačiau dar svarbesni veiksniai už autoritetingajị auklèjimą yra saugus prieraišumas suaugystèje ir demografiniai moteriškos lyties bei amžiaus kintamieji. Tẻvų taikytos elgesio ir psichologinès kontrolès dimensijos nèra reikšmingi dvasingumo prediktoriai, o saugus prieraišumas prie motinos dvasingumą prognozuoja tik netiesiogiai, nes yra reikšmingas vieno svarbiausių dvasingumo etiologijos veiksnių, saugaus prieraišumo prie Kito suaugysteje, prediktorius.

PAGRINDINIAI ŽODŽIAI: humanistinis dvasingumas, savęs aktualizavimas, transcendavimas, gyvenimo prasmé, auklèjimo stiliai, psichologinè kontrolè, elgesio kontrolè, prieraišumo stiliai.
\end{abstract}

\begin{abstract}
The current study $(N=514)$ explores the relationship between humanistic spirituality as it is conceptualised in the proposed Humanistic Spirituality Model and parenting experiences defined herein as authoritative, authoritarian and permissive parenting styles, parental behavioural and psychological control as well as secure and insecure parental and adult attachment styles. The study has found that of the three parenting styles, only the authoritative style is a significant positive predictor of spirituality, though secure attachment in adulthood and the two demographic variables, age and female gender, serve as even more salient predictors. Both parents' behavioural and psychological control forms do not predict humanistic spirituality, whereas secure attachment to the mother furthers spirituality indirectly as it is a significant predictor of one of the most important determinants of spirituality, secure attachment in adulthood.

KEY WORDS: Humanistic spirituality, self-actualisation, transcendence, meaning in life, parenting styles, psychological control, behavioural control, attachment styles.
\end{abstract}

DOI: http://dx.doi.org/10.15181/tbb.v82i1.1958

\section{Ivadas}

Pastaraisiais dešimtmečiais gerokai išaugo empirinių dvasingumo vaidmens žmogaus gyvenime tyrimų skaičius. Kuo nuodugniau ištirti dvasingumo reiškinị svarbu todèl, kad šiandien jị linkstama sieti su asmenybės tobulumu, psichologine branda. Tyrimais nustatyta, kad ir religingumas, ir dvasingumas yra žmogaus adaptyvų funkcionavimą lemiantys veiksniai (Hood ir kt., 2009), teigiamai susiję su fizine ir psichine sveikata (Lawler-Row, 2010) bei polinkiu i prosocialų elgesi 


\section{Simona Kontrimienè}

(Hardy, Carlo, 2005); dvasingumas siejamas ir su gebejjimu kurti bei išlaikyti gerus santuokinius ryšius, laisve nuo priklausomybiu (Snyder, Lopez, 2002), toks mūsų savumas atlieka svarbią funkciją reguliuojant emocijas, vertybes, ịsitikinimus, o tai leidžia mums sukurti tinkamą santykį su tikrove (Gilliam, Franklin, 2004). Panašu, kad dvasingumas didele dalimi lemia mūsų vystymosi kryptis, gyvenimo gerovę (Koenig ir kt., 2005). Pasak P. C. Hill'o ir jo kolegų (2000), dvasingumas yra vienas iš nedaugelio reiškinių, kurie išlieka svarbūs visą žmogaus gyvenimą, dvasinès raidos trajektorija yra lygiagreti kitiems žmogaus vystymosi procesams.

Užsienio šalyse dvasingumo reiškinị skirtingais aspektais tyrẻ nemažai autorių: tirtos dvasingumo sampratos ir šiuolaikiniai matavimo instrumentai (Kapuscinski, Masters, 2010), neurofiziologinès dvasingumo prielaidos (Damasio, 2003), biologiniai atjautos mechanizmai (Davidson, 2002), dvasingumas, kaip aukščiausia rūpos išraiška (Emmons, 1999), kaip sąmoningos patirties ugdymas (Groome, 2001); be to, domètasi religijos ir ịveikos psichologija (Pargament, 2001), skirtingų kultūrų dvasingumo ypatumais (MacKinlay, 2010), dvasingumo istorija, formomis, pagrindais (Waaijman, 2002; Sheldrake, 2007) ir kt.

Lietuvoje dvasingumą daugiausia tiria ugdymo mokslų atstovai (Jovaiša, 2011; Bitinas, 2000; Aramavičiūte, 2005; 2010; Martišauskienè, 2004; 2008), šio reiškinio samprata čia neatskiriama nuo aksiologijos, nes siekiant dvasinès brandos, kyla užduotis atrasti veiksmingų būdų internalizuoti išminties, išganymo, vidinès darnos, santykių tyrumo, brandžios meilès, savigarbos, lygybès, laisvès, santūrumo, tiesos, gerio, grožio ir kitas vertybes, kurios padeda žmogui orientuotis savyje ir pasaulyje, užsiimti refleksija ir saviaukla, ugdytis savimonę.

Tačiau net ir pripažįstant, kad asmens dvasinių vertybių sistema sudaro dvasingumo pamatą, ne mažiau svarbus yra ir pats dvasingumo, kaip daugiamačio konstrukto, turinys bei ji sudarantys komponentai, kurie paprastai įtraukiami i mokslinèje literatūroje siūlomus dvasingumo modelius. Mūsų atliktos dvasingumo reiškinio analizės pagrindu sukurtas Humanistinio dvasingumo modelis ir remiantis juo sudarytas bei validuotas Humanistinio dvasingumo aprašas (Kontrimiené, 2018; 2019). Humanistinio dvasingumo prieiga bene labiausiai atitinka sekuliarizuotą šiandienos realybę ir, kaip teigia K. J. Schneider'is, J. F. T. Bugental'is ir J. F. Pierson'as (2015), geriausiai apibrěžia dvasingumo dèmenis, nes čia didelis dèmesys skiriamas visapusiam asmenybès vystymuisi.

Šio tyrimo, kuriuo siekiama atskleisti dvasingumo, paskirų jo dimensijų ir auklejimo šeimoje patirčių tarpusavio sąsajas akademinio jaunimo imtyje, aktualumą pagrindžia tai, kad Lietuvoje ir užsienio šalyse iki šiol stinga tyrimų apie dvasingumo etiologiją, nors akivaizdu, kad asmens dvasingumą didele dalimi lemia auklëjimas šeimoje, iš kurio kyla pirmosios ir turbūt svarbiausios asmens patirtys. Užsienio šalyse iki šiol atliktuose tyrimuose gilintasi į tai, kaip jaunuolių dva- 
singumas priklauso nuo bendravimo su tèvais kokybės ir dažnumo bei auklejjimo šeimoje stilių (Baumbach ir kt., 2006), kaip tėvų religingumas arba dvasingumas siejasi su įvairiais šeiminio gyvenimo aspektais, tèvų ir vaikų tarpusavio ryšiais bei vaikų raida (Bartkowski ir kt., 2008), tirta dvasinio atsivèrimo motinoms svarba (Brelsford, Mahoney, 2008), auklejimo šeimoje sanktifikacija (Murray-Swank ir kt., 2006) ir kt. Tačiau tiek Lietuvoje, tiek užsienio šalyse trūksta tyrimų, kaip ìvairios auklëjimo šeimoje praktikos prognozuoja dvasingumą, juolab neatlikta tyrimų, kaip dvasingumą lemia tų auklëjimo šeimoje patirčių visuma, į kurią gilinamasi mūsų tyrime. Todèl šiuo darbu tikimasi atsakyti ị svarbius ir Lietuvoje iki šiol mažai tirtus klausimus, atskleisti esmines dvasingumo turinio dimensijas bei tai, kokie auklëjimo šeimoje veiksniai turi dvasingumo ugdymo potencialą.

Kaip tyrimo objektas pasirinktas humanistinio dvasingumo ryšys su auklèjimo šeimoje patirtimis.

Tyrimo problema apibrèžiama klausimu: kokios auklèjimo šeimoje patirtys, šiame darbe apibrèžiamos auklëjimo šeimoje stiliais, tėvų psichologine ir elgesio kontrole bei prieraišumo stiliais, veikia kaip humanistinio dvasingumo etiologijos veiksniai?

Tyrimo tikslas - nustatyti humanistinio dvasingumo, auklejimo šeimoje stilių, tèvų psichologinès ir elgesio kontrolès bei prieraišumo prie tẻvų ir prie Kito suaugysteje stilių sąsajas.

Hipotezè: humanistinį dvasingumą, kurị sudaro savęs aktualizavimo, transcendavimo ir gyvenimo prasmès (iš)gryninimo dimensijos, lemia auklejjimo šeimoje veiksniai - autoritetingasis auklèjimo stilius, tèvų taikoma elgesio, bet ne psichologinè kontrolè, ir saugus prieraišumas prie tėvų bei prie Kito suaugystejje.

Siekiant užsibrèžto tikslo, sprendžiami šie uždaviniai:

1. Pristatyti humanistinio dvasingumo sampratą ir jos pagrindu sukurtą Humanistinio dvasingumo modeli.

2. Atlikti auklëjimo šeimoje patirčių, kaip galimų dvasingumo etiologijos veiksnių, analizę šių patirčių sąryšingumo aspektu.

3. Atskleisti dvasingumo, kaip jis konceptualizuojamas Humanistinio dvasingumo modelyje, sąsajas su auklèjimo šeimoje patirtimis akademinio jaunimo imtyje.

4. Remiantis dvasingumo ir jị lemiančių auklejjimo šeimoje patirčių tyrimo rezultatais, apibrèžti dvasingumo ugdymo(si) prielaidas.

Metodologinè tyrimo prieiga grindžiama postpozityvizmo ir humanistinès psichologijos paradigmomis bei intrapsichinio humanizmo, auklejjimo stiliu, psichologinès ir elgesio kontrolès bei prieraišumo teorijomis.

Tyrimo metodai: sisteminè mokslinès literatūros analizè, kiekybinè apklausa ir statistiné duomenų analizè. 


\section{Simona Kontrimienè}

\section{Humanistinio dvasingumo samprata}

Šiuolaikinès dvasingumo sampratos literatūroje yra tarsi išsidèsčiusios skirtingose kontinuumo pozicijose: vienoje pusejje - sampratos, pagristos religiniais ir teistiniais idealais bei deskriptoriais, kitoje - sekuliarios egzistencialistinès sampratos. Vidurio pozicijoje yra ne tokios radikalios sampratos, talpinančios abieju polių elementus ir nebaigtinị deskriptorių skaičių (žr. Hay, Nye, 2006). Edukologas M. Anthony (2006) skiria šias literatūroje plètojamas dvasingumo prieigas: egzistencialistinis dvasingumas, raidos dvasingumas, psichologinis dvasingumas, humanistinis dvasingumas ir socialinių mokslų dvasingumas. Šias prieigas autorius apibendrintai priskiria natūraliam dvasingumui; apibendrintai vadinamam religiniu dvasingumu autorius priskiria šiuolaikinių religijų, krikščioniškaji, pasaulio religijos ir Naujojo amžiaus dvasingumą. Galiausiai abu sekuliarių ir teistinių prieigų kontinuumo polius sujungia ịvairių sampratų komponentus talpinantis postmodernus dvasingumas.

Mūsų plètojama humanistinio dvasingumo prieiga (žr. Kontrimienė, 2018; 2019) numato žmogaus, žinių ir žinojimo tobulèjimą, žmogaus savęs aktualizavimo ir transcendavimo ịgalintą virsmą bei gyvenimą vadovaujantis gilia tikejjimo ir vidinès darnos ịkvėpta gyvenimo prasmès samprata. Iš aukščiau pateikto dvasingumo sampratų kontinuumo galima spręsti, kad ši dvasingumo prieiga turètų būti suprantama kaip sekuliari ir nesuponuoti teistinių dvasingumo deskriptorių, tačiau tokia humanistinio dvasingumo konceptualizacija turètų būti praturtinta ịtraukiant ị ją tikejjimo aukštesne jèga komponentą, tik svarbu, kad aukštesnè jèga būtų suprantama ne ribojančiai, o turtinančiai ir pozityviai. Tikëjimas čia gali skirtis nuo tradicinių religijų, o Dievo įvaizdis - nuo antropomorfiškų Dievo įvaizdžių, kurie šiuolaikiniam žmogui gali būti nepriimtini.

Prieigos pamatas - humanistinès filosofijos (Humanist Manifestos I, II, III, 2003) ir humanistinès psichologijos (Maslow, 2009 [1954]; 1999 [1961]; 1993 [1971]; Rogers, 1961 [2005]; Elkins ir kt., 1988; Elkins, 1998; 2015) postulatai bei principai. Žmogaus dvasinis augimas čia neatsiejamas nuo savęs aktualizavimo reiškinio, kuris A. Maslow'o (2009) teorijoje apima penkiolika esminių tendencijų ir yra aukštas, tačiau ne aukščiausias kopimo poreikių piramide taškas, nes šis kelias veda ị dar aukštesnę viršūnę - transcendavimą. Tanscendavimas humanistinio dvasingumo prieigoje (žr. Maslow, 1993; Elkins, 2015) yra natūrali savęs aktualizavimo tąsa ir esminis dvasingumo komponentas, papildantis arba keičiantis tradicinị Dievo tikèjimą.

Savęs aktualizavimas ir transcendavimas humanistineje prieigoje suprantami kaip dvasingumo šerdis (žr. Gold, 2013) - tai sutampa su K. I. Pargamento (2001, p. 6) pateikiama dvasingumo apibrèžtimi, pagal kurią dvasingumas šiandien ịvardi- 
jamas kaip ,prasmès, vienovès, susietumo, transcendavimo, aukščiausio žmogiško potencialo siekis“. Šias svarbiausias dvasingumo dedamąsias apima mūsų pateikiamas teorinis-empirinis humanistinio dvasingumo raiškos modelis (Kontrimienè, 2018; 2019), kurị sudaro trys komponentai: savęs aktualizavimas, transcendavimas ir gyvenimo prasmès (iš)gryninimas. Savęs aktualizavimas mūsų modelyje reiškia tikrovės suvokimo brandumą, spontaniškumą, kūrybingumą, viršūnių išgyvenimus, asmeninị augimą, atsiskyrimą, bendrystę su kitais ir santykių gilumą; transcendavimas apibrèžiamas kaip tikèjimas, kad esama kažko daugiau negu tik tai, kas „,matoma“, arba tikejimas antgamtine tikrove, jos išgyvenimas, savęs transcendavimas ir holistinis požiūris ị būtį; gyvenimo prasmès (iš)gryninimas implikuoja gilų gyvenimo ịprasminimą, arba tikejjimo ịkvèptą gyvenimo kryptingumo, tikslingumo, ontologinio reikšmingumo pajautą.

\section{Auklẻjimo šeimoje stiliai, kaip dvasingumo raiškos prielaidos}

Tiriant asmenų auklèjimo patirčių įtaką vaikystèje ir paauglystėje, dažnai orientuojamasi ị mokslinèje literatūroje aprašomus auklëjimo stilius. Auklëjimo stilius gali būti apibrěžiamas kaip ,vaikui perteikiamas nuostatų apie jị kompleksas, sukuriantis emocinị klimatą tèvų elgesio raiškai““ (Darling, Steinberg, 1993, p. 493). Kaip ir dvasingumo, auklèjimo stilių sampratos literatūroje skiriasi, nors dažniausia tiriant ši konstruktą remiamasi raidos psichologès D. Baumrind (1971; 2005; 2013) auklejimo stilių teorija, kurioje aprašomi trys plačiausiai taikomi stiliai.

D. Baumrind (1971) skyrė tris svarbias tėvų elgesio su vaikais dimensijas: (a) vaiko prièmimas / atliepimas ir dalyvavimas jo gyvenime, siekiant užmegzti su juo emocinị ryšį; (b) vaiko kontroliavimas / reiklumas, siekiant skatinti jo brandesnị elgesị ir (c) autonomijos vaikui suteikimas, siekiant skatinti jo savarankiškumą. Skirtingi šių dimensijų raiškos lygmenys atskleidžia tris auklèjimo stilių prototipus: leidžiančiajam stiliui būdingas atliepimas, bet mažas reiklumas / kontroliavimas; autoritariniam (valdingajam) stiliui būdingas didelis kontroliavimas / reiklumas ir mažas atliepimas; autoritetingajam stiliui būdingas didelis atliepimas ir reiklumas ${ }^{1}$.

Leidžiantiji stilių taikantys tèvai stengiasi vaiko nebausti, jị priimti, palankiai reaguoti i jo troškimus ir veiksmus. Jie pozicionuoja save kaip išteklių, kuriuo vaikas gali naudotis kaip tinkamas, o ne kaip idealą, kuriuo jam dera sekti, ir ne kaip aktyvų dalyvi jo gyvenime, kuris formuoja vaiko elgesį. Jie dažniausia leidžia vai-

Dera pažymèti, kad E. Maccoby ir J. Martin'as 1983 m. papilde šiuos tris auklëjimo stilius prideddami ketvirtą, vadinamą aplaidžiuoju, jam būdingas ir mažas atliepimas, ir mažas reiklumas, tačiau D. Baumrind savo tyrimuose retai susidurdavo su šiuo auklejjimo stiliumi, be to, tikètina, kad jị bus patyręs retas studentas, todèl šiame tyrime gilinamasi tik ị D. Baumrind išskirtus auklejjimo stilius. 


\section{Simona Kontrimienè}

kui pačiam reguliuoti savo veiklą, vengia taikyti kontrolę ir neskatina atitikti išorès nustatytų standartų. Siekdami tikslų, tokie tèvai mėgina pasitelkti paaiškinimus ir manipuliacijas, o ne atvirą jẻgą.

Autoritarini (valdingaji) stilių taikantys tèvai stengiasi formuoti, kontroliuoti ir vertinti vaiko elgesi bei nuostatas vadovaudamiesi iš anksto nustatytais, dažnai absoliučiais standartais. Jiems dorybė yra paklusnumas, jie taiko jègą ir bausmes siekdami pažaboti vaiko valią tais atvejais, kai jo elgesys ar ịsitikinimai prieštarauja tam, kas jiems atrodo teisinga. Pasak D. Baumrind (2013), autoritarinị auklëjimo stilių taikantys tèvai dažnai turi perdètai didelių lūkesčių, kurie neatitinka vaiko galimybių.

Trečiaji ir vieninteli tinkamą autoritetingaji stilių taikantys tèvai stengiasi suteikti kryptị vaiko veiksmams ir atsižvelgti ị situaciją. Tokie tèvai vertina vaiko autonomiją, užsispyrimą ir kartu disciplinuotą konformizmą. Jie priima vaiko savybes, kartu nubrèžia elgesio ateityje gaires. Siekdami savo tikslų, tokie tèvai formuoja elgesị taikydami režimą ir pastiprinimą, o ne bausmes (Baumrind, 1971).

Esama tyrimų, kur nustatyta, kad asmenys, kurių tèvai juos auklëjo autoritetinguoju stiliumi, labiau linkę save aktualizuoti, o valdingasis auklèjimo stilius su savęs aktualizavimu koreliuoja neigiamai (Dominguez, Carton, 1997). Gali būti, jog taip yra todèl, kad tinkamą stilių taikantys tèvai skatina vaiko savarankiškumą, leidžia jam jaustis vertinamam. Ir atvirkščiai, jeigu vaikas nuolat baudžiamas ir valdomas geležine ranka, jam save aktualizuoti sunku: pats A. Maslow'as pažymejjo autonomijos svarbą savęs aktualizavimui. Todèl tikètina, kad leidžiantysis ir autoritarinis stiliai nèra palankūs asmens dvasiniam augimui: leidžiantysis - dèl savieigai paliekamos vaiko savireguliacijos, autoritarinis - dèl ribojamos vaiko valios. Palankiausias asmens dvasiniam augimui yra teigiamą savivertę ugdantis ir asmenybės dvasinę brandą skatinantis autoritetingasis auklëjimo stilius.

\section{Prieraišumas, kaip galima taikomo auklèjimo stiliaus išdava}

Akivaizdu, kad auklèjimo stiliai didele dalimi lemia vaiko santykių su tèvais kokybę, kurios svarbi išraiška ir determinantė yra vaiko prieraišumo prie tèvu stilius. Prieraišumo teorijos pradininkas psichiatras J. Bowlby (1973) prieraišuma apibrèžè kaip elgesio formą, kai asmuo pasiekia ir išlaiko artumą kitam, paprastai stipresniam ir / arba išmintingesniam juo besirūpinančiam asmeniui. J. Bowlby (1973) skyrè du esminius individo turimų vidinių modelių aspektus: (a) ar ị asmenị, prie kurio prisirišama, žiūrima kaip ị tokị, kuris apskritai reaguoja į prašymus padėti ir apginti; (b) ar ị save pati žiūrima kaip ị tą, kuriam kiekvienas, ypač jị globojantis žmogus, ateis ị pagalbą (Ten pat). Pirmasis aspektas atskleidžia vaiko 
susikurtą kitų žmonių ịvaizdį, antrasis - vaiko savęs ịvaizdị. Pagal šiuos ịvaizdžius formuojasi prieraišumo stiliai, kuriuos aprašè raidos psichologè M. Ainsworth (Ainsworth ir kt., 1978)². Jos teigimu, anksti vaikystejje artimų žmonių ir savivaizdžių pagrindu susiformuoja arba saugiojo, arba nesaugiojo (nerimastingojo, kitaip ambivalentiškojo, ir vengiančiojo) prieraišumo prie tėvų stiliai.

Saugusis (angl. secure) stilius susiformuoja tada, kai mama nuolat reaguoja i vaiko poreikius ir jis žino, kad visada gali ja pasikliauti. Nesaugusis vengimo (angl. avoidant) stilius gali formuotis tada, kai mama atstumia vaiką jam bandant užmegzti su ja ryši, ir vaikas jaučia, kad negali mama pasikliauti. Trečiaji stilių, kurị autore pavadino ambivalentiškuoju (angl. ambivalent), lemia nenuoseklus mamos elgesys ir nenuspejjamos reakcijos ị vaiko poreikius, todèl vaikas ima nepasitikèti mama.

Susiformuotas prieraišumo stilius bus svarbus ir suaugysteje, nes jis lems visus kitus santykius (Ainsworth, 1989; Bowlby, 1982). Tai aprèpia psichologès K. Bartholomew (1990) J. Bowlby teorijos pagrindu sukurtas keturių prieraišumo stiliu suaugystèje (tik vienas iš jų yra saugusis) modelis. Remiantis šiuo modeliu, jeigu asmuo ị save žiūri kaip ị vertą meilès, o ̣̣ kitus - kaip ị jautrius ir priimančius, jam būdingas saugiojo prieraišumo stilius ir jis gerai jausis artimuose santykiuose bei mokès juos užmegzti. Jeigu asmuo ị save žiūri kaip ị nevertą meilès ir nemylimą, o $\mathfrak{i}$ kitus - palankiai, jis bandys priimti save visų pirma patirdamas kitų žmonių prièmimą, todèl ilgèsis artumo, bet kartu nuolat nerimaus dẻl to, kad gali būti paliktas, bus labai budrus ir pavydus. Tai K. Bartholomew įvardija kaip nerimastingaji prieraišumą (angl. preoccupied), jo atitikmuo M. Ainsworth teorijoje yra ambivalentiškasis stilius. Trečiasis baimingasis vengiantysis (angl. fearful-avoidant) stilius būdingas žmogui, kuris ị save žiūri kaip ị nevertą meilès, o ir kiti jam atrodo nepatikimi, iš jų jis laukia atstūmimo, todèl bijo ir ginasi vengdamas artumo, bet kartu yra priklausomas nuo to, kokị pasitvirtinimą gauna iš išorès. Galiausiai žmogus, kuriam artimiausias ketvirtasis atstumiantysis vengiantysis (angl. dismissive-avoidant) stilius, ị save žiūri teigiamai - kaip ị vertą meilès, bet ị kitus - ne, todèl ginasi nuo nusivylimo vengdamas artimų santykių ir išlaikydamas nepažeidžiamumo pojūtį. Paskutiniai du stiliai atitinka M. Ainsworth teorijos vengiantijji stilių.

Remiantis užsienio šalyse atliktų tyrimų rezultatais (žr. Otway, Carnelley, 2013; Frielingsdorf, 2003) galima kelti prielaidą, kad saugusis prieraišumas teigiamai susijęs su savęs aktualizavimu, transcendavimu ir gyvenimo prasmès išgryninimu,

M. Ainsworth teorija remiasi ịžvalgomis iš eksperimento, kurio metu ji stebejo vienerių metų vaikus jiems nepažistamoje situacijoje. Eksperimentas, kuriame dalyvavo 56 vaikai, vyko laboratorijoje, kur trikampiu buvo sustatytos kẻdès vaikui, jo mamai ir vaikui nepažịstamai moteriai. Šalia vaikui skirtos kẻdès buvo daug žaislų, kad būtų galima stebėti, kiek jis norès tyrinèti aplinką mamai išèjus iš patalpos. Mama turèjo dukart išeiti trims minutèms ir grižti pas vaiką, tik pirmą kartą jis būdavo paliekamas patalpoje su nepažịstama moterimi, antrą kartą visiškai vienas, žiūrèta, kaip jis reaguos ị mamos išèjimus ir sugrịžimus. 


\section{Simona Kontrimienè}

nes aukštesnès jëgos samprata didele dalimi yra tėvams jaučiamų jausmų projekcija.

\section{Laisvès ir kontrolės šeimoje sintezès svarba auklëjimo sẻkmei}

Kontrolès šeimoje reiškinio esmę atskleidžia dvi ji sudarančios dimensijos tèvų elgesio ir psichologinè kontrolè. Psichologo B. Barber'io teigimu, elgesio kontrolè yra teigiama kontrolès forma ir reiškia tèvų pastangas „kontroliuoti ar suvaldyti vaiko elgesį“" (Barber, 1996, p. 3296). Esama tyrimų, kur nustatyta, kad elgesio kontrolès, arba reiklumo, nebuvimas gali lemti vadinamaji , ,altruizmo paradoksą“, kurio esmè ta, kad pasiaukojantys, besąlygiškai savo atžala besirūpinantys, viską leidžiantys ir nieko nereikalaujantys gimdytojai užaugina nesavarankišką, nedèkingą, nei savimi, nei kitais nemokantị pasirūpinti egoistą. Tokiu atveju, kaip rašo Č. Kalenda, „vienų pasiaukojimas virsta kitų egoizmu“ (Kalenda, 1996, p. 18).

Psichologinè kontrolè, kaip ją aprašo B. Barber'is, reiškia tėvų pastangas „kištis ị vaiko psichologinị ir emocinį vystymąsi (mąstymo procesus, saviraišką, emocijas, tèvams jaučiamą prieraišumą)" (Barber, 1996, p. 3296). Remiantis jo sukurtu modeliu, psichologinę kontrolę sudaro šeši komponentai: verbalinès išraiškos slopinimas, jausmų menkinimas, puolimas, kaltès sukèlimas, meilès seikèjimas ir neprognozuojamas emocinis elgesys. Nors kai kurios tẻvų psichologinès kontrolès formos gali būti teigiamos (pvz., aiškinimas vaikui siekiant padidinti jo sąmoningumą ir jautresnị reagavimą ị pasekmes), dažniausia ši auklèjimo dimensija apibrèžiama kaip neigiama kontrolès forma, kuriai būdinga dar ir tai, kad tèvai prieš vaiką naudoja prievartą, pasyvią agresiją, būna jam priešiški ir sukuria tokią aplinką, kurioje jis priimamas tiek, kiek paklūsta tėvų norams (žr. Silk ir kt., 2003).

Iš viso to išplaukia, kad psichologinè kontrolè gali slopinti, o elgesio kontrolè skatinti dvasinę asmenybės brandą. Taip yra todèl, kad elgesio kontrole asmenybė tarsi ịstatoma ị tinkamas raidos vèžes, o psichologinė kontrolè riboja asmens dvasinį tobulëjimą mokydama netikèti meilès ir gyvenimo vertumo besąlygiškumu. Šias ir anksčiau pateiktas prielaidas siekiama patvirtinti arba paneigti toliau pristatomu tyrimu.

\section{Tyrimo metodika}

Tyrimo dalyviai

Tyrimas buvo atliekamas su studentais, studijuojančiais penkiose Lietuvos aukštosiose mokyklose: Kauno technologijos universitete, Klaipedos universitete, 
Vilniaus dailès akademijoje, Vytauto Didžiojo universitete ir Vilniaus universitete. Imtị sudare 514 studentų iš 74 visų mokslo sričių skirtingų pakopų studijų programų (žr. 1 lentelę), 159 (30,9 proc.) vaikinai ir 355 (69,1 proc.) merginos, studentų amžius siekè nuo 18 iki 57 m., amžiaus vidurkis -21 m. (st. nuokr. -2,9). Dalyviai atrinkti taikant tikslinès atrankos metodą.

1 lentelè. Tyrime dalyvavusių studentų skaičiai pagal mokslo sritis ir studijų programas

\begin{tabular}{|l|l|l|l|}
\hline Mokslo sritis & $\begin{array}{l}\text { Studentų } \\
\text { skaičius }\end{array}$ & Studijų pakopa & $\begin{array}{l}\text { Studentų } \\
\text { skaičius }\end{array}$ \\
\hline Biomedicinos mokslai & 138 & Bakalauro studijos & 264 \\
\hline Fiziniai mokslai & 55 & Vientisosios studijos & 93 \\
\hline Humanitariniai mokslai & 145 & Magistrantūra & 108 \\
\hline Socialiniai mokslai & 135 & Doktorantūra & 43 \\
\hline Technologijos mokslai & 41 & Laipsnio nesuteikiančios studijos & 6 \\
\hline
\end{tabular}

\section{Tyrimo instrumentai}

Dvasingumas. Dvasingumas matuotas, remiantis Humanistinio dvasingumo modelio pagrindu sukurtu Humanistinio dvasingumo aprašu (Kontrimienè, 2018). Aprašą sudaro trys skalès ir 40 teiginių, 16 iš jų vertinami priešinga kryptimi. 23 teiginiai matuoja savęs aktualizavimą (pvz.: „Tikiu, kad manęs nepalaužtų net ir didžiausi gyvenimo smūgiai“); 9 teiginiai matuoja transcendavimą (pvz.: „Dažnai pasineriu ị gilias refleksijos būsenas, medituoju ir/ar meldžiuosi“") ir 8 matuoja gyvenimo prasmès (iš)gryninimą (pvz.: „Tikẻjimas man padeda ịžvelgti prasmingus ryšius tarp įvykių, kurie nėra tiesiogiai susiję“). Teiginiai vertinami pagal Likert’o skalę nuo 1 (visiškai nesutinku) iki 7 (visiškai sutinku).

Auklejimo šeimoje patirtys. Auklejimo šeimoje patirtims atskleisti tyrime naudoti trys instrumentai:

Tèvų autoritetingumo klausimynas (angl. Parental Authority Questionnaire - PAQ) (Buri, 1991). Klausimynas sudarytas D. Baumrind teorijos pagrindu ir matuoja vaikysteje bei paauglysteje patirtus autoritetingaji, autoritarini (valdingaji) ir leidžiantiji auklëjimo stilius. PAQ sudaro 30 teiginių, po 10 kiekvienam auklëjimo stiliui, pvz.: „Augdama(s) žinojau, ko tèvai tikisi iš manęs šeimoje, bet kartu galèdavau laisvai aptarti su tèvais jų lūkesčius, jeigu jausdavau, kad jie nepagrịsti“ (autoritetingasis stilius); „Kaskart, kai tèvai liepdavo man ką nors padaryti, jie tikèdavosi, kad tai padarysiu nieko neklausinèdama(s)“ (valdingasis stilius); „Man augant mano tèvams neatrodè, kad aš turiu paklusti elgesio taisyklèms tik todèl, kad jas nustatė kažkas viršesnis“ (leidžiantysis stilius). Teiginiai vertinami pagal Likert'o skalę nuo 1 (visiškai nesutinku) iki 5 (visiškai sutinku). Aukščiau- 
sias vienos ar kitos skalès ịvertis žymi ta skale matuojamo auklëjimo stiliaus dominavimą ${ }^{3}$.

Elgesio kontrolès skalè (angl. Behavioral Control Scale) (Barber ir kt., 2005). Tyrime naudoti penki B. Barber'io sukurti teiginiai, matuojantys, kiek tèvai žino apie tai, kuo gyvena jų vaikas, ir kiek jie stebi jo veiklą. Dalyviai pildè atskirai motinos ir tévo formas ir turèjo atsakyti, kiek jų tėvai žinodavo apie tai, kur jie būdavo vakarais, kam leisdavo savo pinigus, su kuo draugaudavo ir kt. Teiginiai vertinti nuo 1 (nežinodavo) iki 3 (gerai žinodavo).

Psichologinès kontrolès skalè - jaunimo savistata (angl. Psychological Control Scale - YSR) (Barber, 1996). Skalę sudaro dvi atskiros motinos ir tèvo formos, kurias sudaro po 16 vienodų penkias psichologinès kontrolès dimensijas matuojančių teiginių: verbalinès išraiškos slopinimas (pvz.: „Kai noriu ką nors pasakyti, ji pakeičia temą“); jausmų menkinimas (pvz.: „Nuolat bando paveikti mano jausmus ar mintis“); puolimas (pvz.: „Kaltina mane dèl kitų mūsų šeimos narių problemų“); kaltès sukèlimas (pvz.: „Vis kartoja, ką yra dèl manęs padariusi“); meilès seikèjimas (pvz.: „Kai ją nuviliu, vengia ị mane žiūrèti“); neprognozuojamas emocinis elgesys (pvz.: „Tai rodo man šilumą, tai kritikuoja“). Teiginiai vertinami pagal trijų balų Likert'o skalę nuo 1 (nepanašu i ja (ji)) iki 3 (labai panašu i ja ja (ji)).

Prieraišumas. Siekiant atskleisti, kaip dvasingumą prognozuoja prieraišumo prie tėvų, o suaugysteje - ir prie kitų žmonių, stiliai, tyrime taikyti du prieraišumo matai:

Prieraišumo prie tèvų ir bendraamžių aprašas (angl. Inventory of $P a$ rent and Peer Attachment - IPPA) (Armsden, Greenberg, 1987). IPPA matuojami afektiniai ir kognityviniai jaunuolių santykių su tèvais ir artimais draugais aspektai. Aprašą sudaro 25 teiginiai apie motiną, 25 teiginiai apie tẻvą ir 25 teiginiai apie draugą, teiginiai vertinami pagal penkių balų skalę. Išskiriami trys platūs matai: abipusio pasitikèjimo lygmuo (pvz.: „Jaučiu, kad mano těčiui puikiai sekasi būti téčiu“); bendravimo kokybė (pvz.: „Kai man reikia išsipasakoti, kad palengvètų, galiu kreiptis ị mamą“); pykčio ir susvetimejjimo laipsnis (pvz.: „Pykstu ant tèčio"). Remiantis gautais įverčiais, išskiriami saugusis, ambivalentiškasis (nerimastingasis) ir vengiantysis prieraišumo stiliai ${ }^{4}$.

3 Nors PAQ gali būti naudojamas atskirai vertinant tèvo ir motinos taikytus auklèjimo stilius, šiame tyrime dalyviai turèjo ịvertinti abiejų tẻvų taikytą auklējimą, tarsi išvesdami bendrą patirties dedamają, nes kitaip kiekvienu atveju turètų būti atsižvelgiama ir ị tai, kurio iš tėvų įtaka buvo stipresnè, o tai būtų sunku išmatuoti. Toks sprendimas grindžiamas ir B. Soenens'o su kolegomis (2005) atliktu tyrimu, kuriuo nustatyta, kad paauglių pateikiami motinų ir tėvų auklèjimo stilių vertinimai gali būti sudèti ị bendrą ịvertị, nes dažnai jie reikšmingai nesiskiria.

4 Tyrime naudotos tik motinos ir tèvo formos. İverčiai skirstomi i žemą (1), vidutinị (2) ir aukštą (3) trečdalius: saugusis prieraišumo stilius nustatomas, jei Susvetimejjimo ịvertis nèra aukštas, o Pasitikejimo ir / arba Bendravimo ịvertis - aukštas (t. y. 3), o kitas - vidutinis (t. y. 2). Šis stilius nustatomas ir tada, kai ir Pasitikejjimo, ir Bendravimo įverčiai yra aukšti, o Susvetimejjimo ịvertis - žemas. Ambivalentiškasis stilius nustatomas, jeigu Pasitikèjimo ir Bendravimo ịverčiai 
Santykių klausimynas (angl. The Relationships Questionnaire - RQ) (Bartholomew, Horowitz, 1991). Klausimyną sudaro keturios trumpos pastraipos, kuriomis apibūdinami keturi galimi prieraišumo prie artimų žmonių suaugystejje modeliai, atitinkantys saugujį, nerimastingaji, baimingaji vengiantiji ir atstumiantiji vengiantiji stilius. Stiliai vertinti pagal skalę nuo 1 (man visiškai nebūdinga) iki 7 (man labai būdinga), dalyvių prašyta nepateikti vienodų vertinimų. Pavyzdžiui, nerimastingaji stilių nusako tokia pastraipa: „Negerai jaučiuosi, kai reikia suartėti su kitais žmonemmis. Noriu artimų santykių, bet man sunku visiškai pasitikèti kitais arba tapti nuo jų priklausomam(-ai). Bijau, kad, jei leisiu sau per daug su jais suarteti, liksiu įskaudinta(s).“

Dera pridurti, kad visų šiame tyrime naudotų instrumentų autoriai leidžia naudoti instrumentus tyrimų tikslais be atskiro sutikimo. Instrumentus iš anglų i lietuvių kalbą išvertè tyrimo autorè, profesionali vertèja, kitas profesionalus vertejjas atliko visų teiginių grịžtamuosius vertimus ị anglų kalbą, o nepriklausomas ekspertas ịvertino, kiek atversti teiginiai sutampa su originaliais. Statistiniam tyrimo duomenų apdorojimui naudotas programinis paketas SPSS 21.0. Rezultatai ịvertinti kaip statistiškai reikšmingi, kai reikšmingumo lygmuo $p<0,05$.

\section{Tyrimo rezultatai}

Pirmajame analizės etape, remiantis šio tyrimo imties duomenimis, apskaičiuoti visų, išskyrus vieną, tyrime naudotų instrumentų teiginių vidinio suderintumo (Cronbach'o $\alpha$ ) koeficientai 5 . Visų koeficientų reikšmės pakankamai aukštos (viršija 0,7 reikšmę), todèl galima teigti, kad tyrimo duomenys patikimi.

Skirtumai pagal lytị. Taikant Stjudent'o t ir Mann-Whitney U kriterijus siekta išsiaiškinti, ar vaikinai ir merginos skiriasi pagal ranginių kintamujų - humanistinio dvasingumo, auklèjimo stilių, psichologinès ir elgesio kontrolès bei prieraišumą prie tèvų lemiančių dimensijų (susvetimejjimo, bendravimo su tèvais ir pasitikèjimo jais) ịverčius. Atlikus analizę nustatyta (žr. 2 lentelę), kad šio tyrimo dalyviai statistiškai reikšmingai skiriasi pagal svarbiausią kintamaji - bendrą Humanistini dvasingumą ( $p=0,001)$ : merginos surinko gerokai aukštesnius HDA ìverčius nei vaikinai ( 159 vs $147, p=0,001)$. Merginos surinko ir statistiškai reikšmingai aukštesnius transcendavimo $(30,1$ vs $25,5, p=0,001)$ bei gyvenimo prasmès (iš)gryninimo (33,2 vs $26,6, p=0,000)$ įverčius. Reikšmingai vaikinai nuo merginų nesiskyrè tik pagal HDA Savęs aktualizavimo skalès įverčių vidurkius $(94,6$ vs $94,8, p=0,911)$.

yra vidutiniai, o Susvetimejjimo nèra žemas. Vengiantysis stilius - jeigu ir Pasitikejjimo, ir Bendravimo įverčiai žemi, o Susvetiméjimo - vidutinis arba aukštas.

5 Santykių klausimynui (Bartholomew, Horowitz, 1991) Cronbach'o $\alpha$ koeficientai neskaičiuoti, nes kiekvienas klausimyno matuojamas prieraišumo suaugystejje stilius apibūdinamas tik viena pastraipa. 


\section{Simona Kontrimienè}

Be to, Mann-Whitney U testu tikrinta, ar vaikinai ir merginos skiriasi pagal patirtus auklejjimo stilius, kuriuos matuoja trys PAQ auklejjimo stilių skalès. Palyginus skalių įverčiu vidurkius paaiškejjo (žr. 2 lentelę), kad merginos dažniau auklètos autoritetinguoju stiliumi $(32,8$ vs 30,8$)$ ir kiek rečiau - valdinguoju stiliumi (26 vs 27,5), tačiau šie skirtumai statistiškai nereikšmingi ( $p=0,053$ ir $p=0,092)$. Vaikinai ir merginos skiriasi tik pagal patirtą leidžiantijį auklèjimo stilių: merginos statistiškai reikšmingai dažniau nurodè, kad auklètos šiuo stiliumi $(28,3$ vs 26,5 , $p=0,033)$.

Analizuojant skirtumus tarp vaikinų ir merginų pagal tėvų taikytas psichologinę ir elgesio kontrolę bei prieraišumą prie tėvų lemiančias dimensijas (pasitikejjimą tèvais, bendravimą ir susvetimèjimą) išryškejo tik du statistiškai reikšmingi skirtumai: mamos šiek tiek stipriau kontroliuoja merginų elgesį $(12,8$ vs $12,3, p=0,022)$ ir merginoms būdingas aukštesnis bendravimo su mamomis kokybės lygmuo $(31,3$ vs $29,6, p=0,036)$.

2 lentele. Studentų (vaikinų ir merginų) įverčių vidurkiai, standartiniai nuokrypiai ir vidurkių skirtumų reikšmingumo lygmuo

\begin{tabular}{|c|c|c|c|c|c|c|c|}
\hline \multirow{2}{*}{ Humanistinis dvasingumas } & \multicolumn{2}{|c|}{ Visa imtis } & \multicolumn{2}{|c|}{ Vaikinai } & \multicolumn{2}{|c|}{ Merginos } & \multirow{2}{*}{$p$} \\
\hline & Vid. & St. $n$. & Vid. & St. $\mathbf{n}$. & Vid. & St. $n$. & \\
\hline HDA & 156 & 30,1 & 147 & 28 & 159 & 30,2 & 0,001 \\
\hline HDA Savęs aktualizavimas & 94,8 & 14,9 & 94,6 & 13,9 & 94,8 & 15,1 & 0,911 \\
\hline HDA Transcendavimas & 29,5 & 12,2 & 25,5 & 11,1 & 30,1 & 12,3 & 0,001 \\
\hline $\begin{array}{l}\text { HDA Gyvenimo prasmès } \\
\text { (iš)gryninimas }\end{array}$ & 31,6 & 9,3 & 26,6 & 9,9 & 33,2 & 8,8 & 0,000 \\
\hline \multirow{2}{*}{ Tėvų auklèjimo stiliai } & \multicolumn{2}{|c|}{ Visa imtis } & \multicolumn{2}{|c|}{ Vaikinai } & \multicolumn{2}{|c|}{ Merginos } & $p$ \\
\hline & Vid. & St. n. & Vid. & St. n. & Vid. & St. n. & \\
\hline Autoritetingasis & 32,2 & 8,3 & 30,8 & 8 & 32,8 & 8,3 & 0,053 \\
\hline Valdingasis & 26,6 & 7,9 & 27,5 & 7,9 & 26 & 7,9 & 0,092 \\
\hline Leidžiantysis & 27,7 & 6,7 & 26,5 & 6,3 & 28,3 & 6,8 & $\mathbf{0 , 0 3 3}$ \\
\hline \multirow{2}{*}{ Tèvų kontrolè } & \multicolumn{2}{|c|}{ Visa imtis } & \multicolumn{2}{|c|}{ Vaikinai } & \multicolumn{2}{|c|}{ Merginos } & \\
\hline & Vid. & St. n. & Vid. & St. n. & Vid. & St. $n$. & $p$ \\
\hline $\begin{array}{l}\text { Motinos psichologinè kon- } \\
\text { trolè }\end{array}$ & 23,2 & 7,4 & 23,7 & 7,8 & 23,1 & 7,4 & 0,524 \\
\hline Tėvo psichologinè kontrolè & 19,9 & 8,5 & 20 & 9,8 & 19,8 & 8,2 & 0,988 \\
\hline
\end{tabular}




\begin{tabular}{|c|c|c|c|c|c|c|c|}
\hline \multirow{2}{*}{ Humanistinis dvasingumas } & \multicolumn{2}{|c|}{ Visa imtis } & \multicolumn{2}{|c|}{ Vaikinai } & \multicolumn{2}{|c|}{ Merginos } & \multirow{2}{*}{$p$} \\
\hline & Vid. & St. $n$. & Vid. & St. n. & Vid. & St. $n$. & \\
\hline Motinos elgesio kontrolè & 12,6 & 2,4 & 12,3 & 2,3 & 12,8 & 2,4 & 0,022 \\
\hline Tèvo elgesio kontrolè & 9,4 & 4 & 9 & 4 & 9,6 & 4 & 0,108 \\
\hline \multirow{2}{*}{ Prieraišumas prie tėvų } & \multicolumn{2}{|c|}{ Visa imtis } & \multicolumn{2}{|c|}{ Vaikinai } & \multicolumn{2}{|c|}{ Merginos } & \\
\hline & Vid. & St. n. & Vid. & St. n. & Vid. & St. n. & $p$ \\
\hline Susvetimejjimas su motina & 15 & 5,7 & 15,1 & 4,8 & 14,9 & 5,9 & 0,760 \\
\hline Susvetimèjimas su tėvu & 15,1 & 7,1 & 15,3 & 6,7 & 15,2 & 7,3 & 0,874 \\
\hline Bendravimas su motina & 31 & 9,5 & 29,6 & 7,9 & 31,3 & 9,8 & 0,036 \\
\hline Bendravimas su tèvu & 23,1 & 9,7 & 23,4 & 9,3 & 23 & 9,8 & 0,687 \\
\hline Pasitikejjimas motina & 39,6 & 9,9 & 39,5 & 8,3 & 39,6 & 10,2 & 0,274 \\
\hline Pasitikejjimas tėvu & 30,1 & 11,9 & 29,3 & 11,5 & 30,6 & 12 & 0,077 \\
\hline
\end{tabular}

Šiame analizès etape taikant chi kvadrato homogeniškumo kriterijų dar tikrinta, ar lytis lemia prieraišumo prie tèvų ir suaugysteje stilius. Mūsų rezultatai atskleidè, kad nei prieraišumo prie tèvų, nei prieraišumo suaugysteje stiliai nuo lyties nepriklauso: mūsų imties merginos ir vaikinai nesiskiria nei pagal prieraišumo prie motinos $\left(\chi^{2}=0,381, d f=2, p=0,827\right)$, nei pagal prieraišumo prie tèvo $\left(\chi^{2}=1,306\right.$, $d f=2, p=0,520)$, nei pagal prieraišumo suaugysteje $\left(\chi^{2}=6,183, d f=3, p=0,103\right)$ stilius. İdomu tai, kad ir vaikinams, ir merginoms labiausiai būdingas prieraišumas prie motinos yra saugusis (68 ir 71 proc.), prie tèvo - ambivalentiškasis (61 ir 54 proc.), o suaugysteje vaikinams (31 proc.) - nerimastingasis, merginoms - saugusis (32 proc.).

Humanistinio dvasingumo ir auklejjimo šeimoje patirčių sąsajos. Paskesniame analizès etape skaičiuotos koreliacijos (žr. 3 lentelę) tarp visų tyrime nagrinèjamų kintamujjų ${ }^{6}$. Akivaizdu, kad mūsų tyrime svarbiausi yra ryšiai tarp dvasingumo dimensijų, kaip jos konceptualizuojamos mūsų modelyje, ir trijų auklejimo stilių, kaip jie konceptualizuojami D. Baumrind teorijoje, todèl detaliau aptarsime tik juos.

Remiantis mūsų tyrimo rezultatais galima teigti, kad ir merginų, ir vaikinų autoritetingasis auklëjimas reikšmingai koreliuoja su bendru humanistiniu dvasingumu (merginoms $r=0,142, p<0,05$; vaikinams $r=0,365, p<0,01$ ), nors vaikinams šis ryšys stipresnis; be to, su autoritetingojo auklejimo stiliumi teigiamai susijęs ir merginų, ir vaikinų transcendavimo lygmuo $(r=0,119, p<0,05 ; r=0,226$, $p<0,01$ ), o vaikinų autoritetingasis auklèjimas susijęs dar ir su jų gyvenimo pras-

${ }_{6}$ Kadangi vaikinai ir merginos reikšmingai skiriasi pagal HDA j̣verčius, koreliacijos jiems skaičiuotos atskirai. 
Simona Kontrimienè

\begin{tabular}{|c|c|c|c|c|c|c|c|c|c|c|c|c|c|c|}
\hline 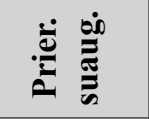 & $\frac{*}{6}$ & $\frac{*}{N^{*}}$ & $\because$ & $\overrightarrow{0}$ & : & $0_{0}^{0}$ & $\stackrel{*}{*}$ & $\stackrel{*}{m}$ & $\begin{array}{l}\tau \\
\delta \\
0\end{array}$ & $\because$ & $\stackrel{\infty}{0}$ & $\overrightarrow{0}$ & a & 1 \\
\hline 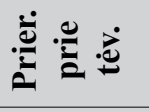 & $\stackrel{*}{\stackrel{*}{0}}$ & $\stackrel{*}{ \pm}$ & $\overrightarrow{0}$ & ?n & $\begin{array}{l}\text { के } \\
\text { ले } \\
0\end{array}$ & 离 & 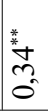 & 烍 & $\frac{*}{*}$ & \begin{tabular}{l}
$*$ \\
\multirow{2}{*}{} \\
$\hat{0}$ \\
$i$
\end{tabular} & $\begin{array}{l}* \\
i n \\
n \\
0 \\
i\end{array}$ & 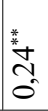 & 1 & $\stackrel{*}{ \pm}$ \\
\hline 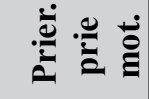 & $\stackrel{*}{0}$ & $\frac{F^{*}}{0^{\circ}}$ & 8 & $\overline{0}$ & $\begin{array}{l}* \\
n \\
0 \\
0\end{array}$ & $\stackrel{*}{*}$ & $\begin{array}{l}* \\
\text { m. } \\
0^{2}\end{array}$ & $\stackrel{6}{6}_{0}^{0}$ & $\stackrel{*}{2}$ & $\begin{array}{l}\frac{*}{*} \\
\text { m. } \\
0\end{array}$ & 草 & I & $\begin{array}{l}* \\
i^{n} \\
n \\
0\end{array}$ & तू \\
\hline 我芒泀 & $\begin{array}{l}8 \\
0 \\
0\end{array}$ & 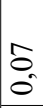 & 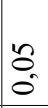 & ơ & $\begin{array}{l}\tilde{x}_{0} \\
\text { en. } \\
0\end{array}$ & $\begin{array}{l}0 \\
0 \\
0 \\
1\end{array}$ & $\overrightarrow{0}$ & $\frac{*}{9}$ & O. & 童 & 1 & $\begin{array}{l}* \\
* \\
0 \\
0\end{array}$ & $\frac{*}{F^{*}}$ & $\overline{0}$ \\
\hline
\end{tabular}

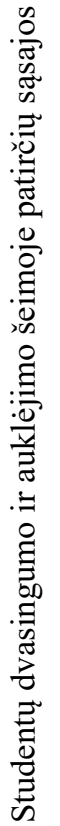

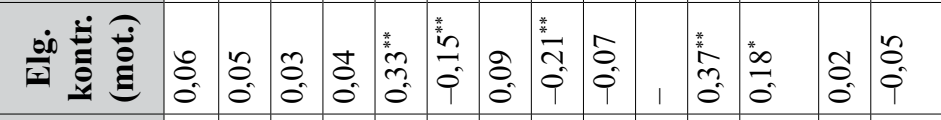

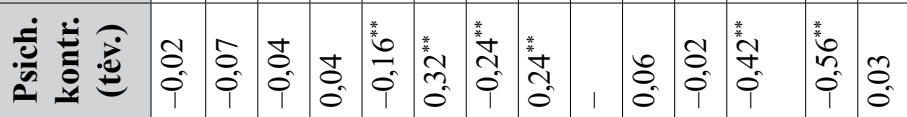

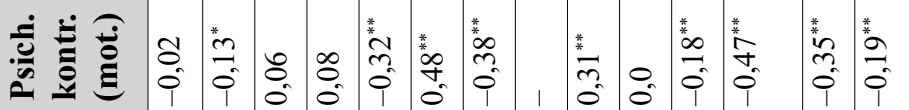

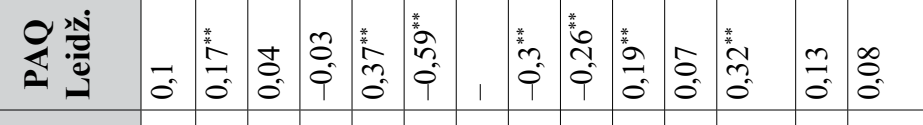

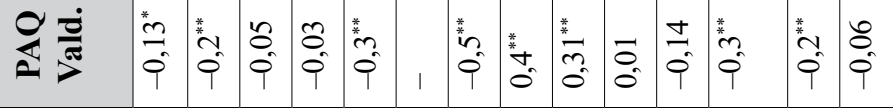

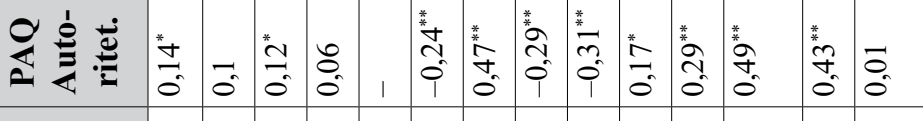

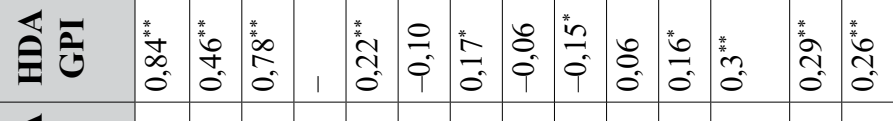

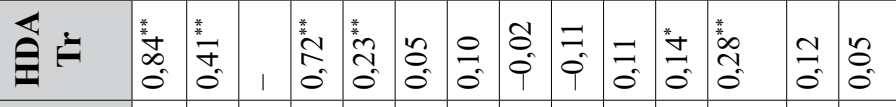

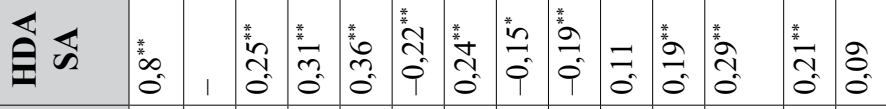

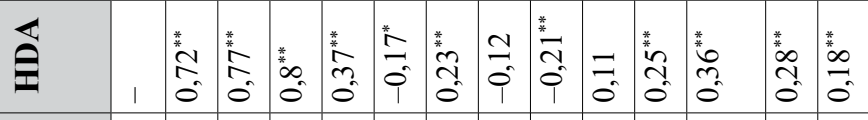

焉

:

$\stackrel{2}{\Xi}$

:

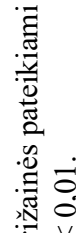

厾

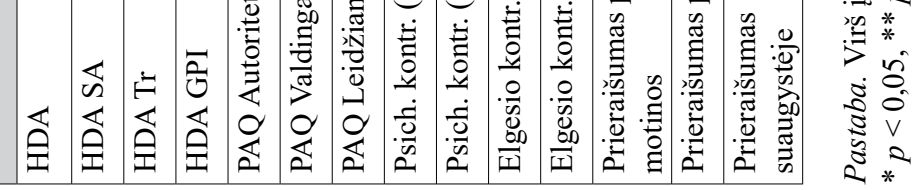


mès (iš)gryninimu $(r=0,220, p<0,01)$ bei savęs aktualizavimu $(r=0,363, p<$ $0,01)$.

Rezultatai atskleidè ir tai, kad valdingasis auklëjimas neigiamai koreliuoja su merginų ir vaikinų bendru dvasingumu, nors vaikinų atveju šis ryšys kiek stipresnis (merginų $r=-0,133, p<0,05$; vaikinų $r=-0,167, p<0,05$ ). Visai tyrimo imčiai nustatytas dar stipresnis neigiamas ryšys tarp valdingojo auklejjimo ir savęs aktualizavimo (merginų $r=-0,202, p<0,01$; vaikinų $r=-0,218, p<0,01$ ).

Galiausiai leidžiantysis auklèjimo stilius merginoms nèra reikšmingai susijęs su bendru dvasingumu, o vaikinams ši sąsaja labai reikšminga ir teigiama $(r=0,230$, $p<0,01)$. Be to, vaikinams šis stilius reikšmingai koreliuoja su dviem dvasingumo dimensijomis - savęs aktualizavimu $(r=0,244, p<0,01)$ ir kiek silpniau - su gyvenimo prasmès (iš)gryninimu $(r=0,172, p<0,05)$, merginoms - tik su savęs aktualizavimu $(r=0,165, p<0,01)$.

Humanistinio dvasingumo prognozavimas. Tolesniame rezultatų analizès etape siekta atskleisti, kaip tyrimui svarbūs kintamieji prognozuoja dvasingumo lygmenis. Tuo tikslu atlikta hierarchinès tiesinès regresijos analizè visai tyrimo imčiai, kurios metu sudaryti trys dvasingumo prognozavimo pagal paskirus nepriklausomuosius kintamuosius modeliai (žr. 4 lentelę).

4 lentele. Humanistinį dvasingumą prognozuojantys veiksniai

\begin{tabular}{|c|c|c|c|c|c|}
\hline Hierarchinės regresijos modeliai & B & $S E$ & $\boldsymbol{\beta}$ & $t$ & $p$ \\
\hline \multicolumn{6}{|l|}{ I modelis } \\
\hline Lytis & 11,16 & 3,64 & 0,142 & 3,07 & 0,00 \\
\hline Amžius & 0,86 & 0,37 & 0,112 & 2,34 & 0,02 \\
\hline Autoritetingasis auklejjimo stilius & 0,41 & 0,19 & 0,135 & 2,56 & 0,01 \\
\hline Valdingasis auklèjimo stilius & $-0,17$ & 0,22 & $-0,04$ & $-0,76$ & 0,45 \\
\hline Leidžiantysis auklejjimo stilius & 0,24 & 0,27 & 0,05 & 0,89 & 0,37 \\
\hline \multicolumn{6}{|l|}{$R^{2}=0,05, \mathrm{~F}(5,443)=5,546, p=0,00$} \\
\hline II modelis & $B$ & $S E$ & $\beta$ & $t$ & $p$ \\
\hline Lytis & 10,88 & 3,65 & 0,139 & 2,98 & 0,00 \\
\hline Amžius & 0,89 & 0,37 & 0,116 & 2,27 & 0,02 \\
\hline Autoritetingasis auklejimo stilius & 0,47 & 0,21 & 0,128 & 2,40 & 0,02 \\
\hline Valdingasis auklejjimo stilius & $-0,21$ & 0,24 & $-0,06$ & $-0,87$ & 0,39 \\
\hline Leidžiantysis auklejjimo stilius & 0,23 & 0,27 & 0,05 & 0,84 & 0,4 \\
\hline Psichologinè kontrolè (mot.) & 0,23 & 0,22 & 0,06 & 1,05 & 0,3 \\
\hline Psichologinè kontrolè (tèv.) & $-0,07$ & 0,19 & $-0,02$ & $-0,35$ & 0,73 \\
\hline Elgesio kontrolè (mot.) & 0,34 & 0,64 & 0,03 & 0,53 & 0,59 \\
\hline Elgesio kontrolè (tèv.) & 0,29 & 0,41 & 0,04 & 0,71 & 0,48 \\
\hline \multicolumn{6}{|l|}{$R^{2}=0,06, F(9,439)=3,32, p=0,00$} \\
\hline III modelis & $B$ & $S E$ & $\beta$ & $t$ & $p$ \\
\hline
\end{tabular}


Simona Kontrimienè

\begin{tabular}{|l|l|l|l|l|l|}
\hline Hierarchinės regresijos modeliai & $\boldsymbol{B}$ & $\boldsymbol{S} \boldsymbol{\beta}$ & $\boldsymbol{\beta}$ & $\boldsymbol{t}$ & $\boldsymbol{p}$ \\
\hline Lytis & 10,56 & 3,88 & 0,135 & 2,72 & 0,007 \\
\hline Amžius & 1,15 & 0,41 & 0,144 & 2,84 & 0,005 \\
\hline Autoritetingasis auklëjimo stilius & 0,17 & 0,24 & 0,05 & 0,71 & 0,48 \\
\hline Valdingasis auklëjimo stilius & $-0,11$ & 0,25 & $-0,03$ & $-0,45$ & 0,65 \\
\hline Leidžiantysis auklëjimo stilius & 0,25 & 0,29 & 0,06 & 0,87 & 0,38 \\
\hline Psichologinè kontrolė (mot.) & 0,41 & 0,28 & 0,1 & 1,49 & 0,14 \\
\hline Psichologiné kontrolè (tėv.) & $-0,005$ & 0,26 & $-0,001$ & $-0,02$ & 0,98 \\
\hline Elgesio kontrolė (mot.) & $-0,22$ & 0,82 & $-0,02$ & $-0,27$ & 0,79 \\
\hline Elgesio kontrolė (tèv.) & 0,28 & 0,67 & 0,03 & 0,42 & 0,67 \\
\hline Prieraišumas prie motinos & 6,05 & 3,22 & 0,12 & 1,88 & 0,06 \\
\hline Prieraišumas prie tėvo & 2,51 & 3,25 & 0,05 & 0,78 & 0,44 \\
\hline Prieraišumas suaugystėje & 3,45 & 1,42 & 0,121 & 2,43 & 0,015 \\
\hline$R^{2}=0,09, F(12,391)=3,08, p=0,00$ & & & & & \\
\hline
\end{tabular}

Pirmajame modelyje ị regresijos lygtị itraukti penki nepriklausomieji kintamieji: lytis, amžius ir trys auklèjimo vaikystejje stiliai. Rezultatai atskleidè, kad, nors šis modelis statistiškai labai reikšmingas, jis paaiškina visai nedidelę dvasingumo kintamojo dispersijos dali $\left(R^{2}=0,05, F(5,443)=5,546, p=0,00\right)$ ir pagal ji reikšmingai teigiamai humanistinio dvasingumo raišką prognozuoja tik lytis $(\beta=0,142, t=3,07, p=0,00)$, amžius $(\beta=0,112, t=2,34, p=0,02)$ ir autoritetingasis auklëjimo stilius $(\beta=0,135, t=2,56, p=0,01)$. Valdingasis auklejjimas yra neigiamas, tačiau nereikšmingas dvasingumo prediktorius, o leidžiantysis auklèjimo stilius taip pat neleidžia reikšmingai prognozuoti dvasingumo lygmens, nors ši sąsaja teigiama.

Antrajame modelyje (žr. 4 lentelę) ị regresijos lygtị ịtraukti dar keturi kintamieji: motinos ir tèvo psichologinè bei motinos ir tèvo elgesio kontrolè. Rezultatai atskleidè, kad šis modelis taip pat statistiškai labai reikšmingas ir paaiškina šiek tiek didesnę dvasingumo kintamojo dispersijos dalị nei pirmasis $\left(R^{2}=0,06\right.$, $F(9,439)=3,32, p=0,00)$. Šiame modelyje humanistinį dvasingumą reikšmingai prognozuoja tie patys kintamieji kaip ir pirmajame, šie prediktoriai yra lytis $(\beta=0,139, t=2,98, p=0,00)$, amžius $(\beta=0,116, t=2,27, p=0,02)$ ir autoritetingasis auklejjimas $(\beta=0,128, t=2,40, p=0,02)$. Tai reiškia, kad moteriška lytis, vyresnis amžius ir autoritetingas auklèjimas lemia didesnị dvasingumą.

Trečiajame hierarchinès regresijos modelyje (žr. 4 lentelę) į regresijos lygtị kartu su auklëjimo stilių ir tèvų kontrolès kintamaisiais įtraukti dar ir prieraišumo prie motinos, tèvo bei prieraišumo suaugystejje kintamieji. Paaiškèjo, kad, kai ị lygtị ịtraukiami visi mūsų tyrime analizuojami kintamieji, tik trys iš jų statistiškai reikšmingai prognozuoja humanistinio dvasingumo lygị, ir šis modelis paaiškina didžiausią dvasingumo kintamojo dispersijos dalị $\left(R^{2}=0,09, F(12,391)=3,08\right.$, 
$p=0,00)$. Dvasingumą prognozuojantys kintamieji yra lytis, amžius ir prieraišumo suaugystèje stilius: moteriškos lyties, vyresnių ir suaugysteje saugiai prie artimujų prisirišusių asmenų dvasingumas linkęs būti aukštesnis.

Visi kiti kintamieji, net ir autoritetingasis auklejjimas, santykinai tampa nereikšmingi. Svarbu tai, kad mūsų anksčiau atlikta koreliacinė analizè atskleidè, jog prieraišumas suaugystejje nekoreliuoja su autoritetinguoju auklèjimu (merginų atveju $r=0,06, p>0,05$, vaikinų $-r=0,01, p>0,05$ ), todèl mūsų tyrimo rezultatai nepatvirtina prielaidos, kad saugusis prieraišumas suaugysteje medijuoja sąsają tarp autoritetingojo auklējimo ir dvasingumo: šis kintamasis prognozuoja dvasingumą nepaisant auklëjimo stiliaus.

Paaiškejjus, kad saugusis prieraišumas suaugystèje yra svarbus dvasingumo prediktorius, atlikta atskira tiesinès regresijos analizè, kuri atskleidè, jog iš visų tyrime nagrinètų kintamujų sauguji prieraišumą suaugysteje prognozuoja tik saugusis prieraišumas prie motinos $\left(\beta=0,131, R^{2}=0,02, F(2,78)=1,439, p<0,01\right)$. Tai leidžia teigti, kad saugusis prieraišumas prie motinos lemia teigiamą asmens požiūrị i Kitą, o per tai - ir jo dvasingumą, ši ịtaka reiškiasi per patirčių šeimoje suformuotą artimą santykị su mama.

Taigi pagrindine iš mūsų tyrimo rezultatų išplaukianti išvada: nors svarbiausias mūsų tirtas auklèjimo šeimoje patirtis apimantis veiksnys - autoritetingasis auklejjimo šeimoje stilius - yra svarbus dvasingumo etiologijai, nes dviejuose iš trijų hierarchinès regresijos modelių toks auklëjimo stilius yra statistiškai reikšmingas teigiamas dvasingumo prediktorius, vis dèlto ị regresijos modelị ịtraukus visus tyrime analizuotus kintamuosius išryškejjo tai, kad dar svarbesni dvasingumo prediktoriai yra saugusis prieraišumas suaugysteje, moteriška lytis ir amžius. Šie rezultatai nemaža dalimi patvirtina pagrindinę tyrimo hipotezę, kad humanistinị dvasinguma, kurị sudaro savęs aktualizavimo, transcendavimo ir gyvenimo prasmès (ǐ̌) gryninimo dimensijos, lemia auklëjimo šeimoje veiksniai - autoritetingasis auklëjimo stilius, tèvu taikoma elgesio, bet ne psichologinè kontrolè, ir saugus prieraišumas prie tèvu bei prie Kito suangystejje: mūsų tyrimas atskleidè, kad, nors autoritetingasis auklejjimas yra reikšmingas dvasingumo prediktorius, saugiojo prieraišumo prie Kito suaugysteje ịtaka didesné; tèvų taikytos elgesio ir psichologinės kontrolès dimensijos nèra reikšmingi dvasingumo prediktoriai, o saugusis prieraišumas prie motinos dvasingumą prognozuoja tik netiesiogiai, nes yra reikšmingas vieno svarbiausių dvasingumo etiologijos veiksnių - saugiojo prieraišumo prie Kito suaugysteje, prediktorius. Tačiau kadangi visi trys tyrimo regresijos modeliai paaiškina tik nedidelę dvasingumo kintamojo dispersijos dalị, akivaizdu, kad ši sudètingą asmenybès savumą lemia ir daug kitụ i š ši tyrimą bei regresijos lygtis neįtrauktų gyvenimiškos patirties veiksnių, kuriuos galbūt atskleis kiti tyrimai. 


\section{Diskusija}

Dvasingumas - tai sudėtingas daugiamatis konstruktas, kurio turinio dèmenys gali būti skirtingai suprantami (žr. Hill ir kt., 2000; Kapuscinski, Masters, 2010). Kartu visada tai gilesnès savasties negu tik fizinis, emocinis ir mentalinis kūnas atradimas, kelias ị teigiamą santykị su pasauliu, vidinę harmoniją, aukštesnę būties kokybę, o per tai - ir ị laimès bei gyvenimo prasmès pajautą.

Atlikdami tyrimą gilinomès ị tai, kaip humanistinis dvasingumas, taikant mūsų siūlomą modeli apimantis savęs aktualizavimą, transcendavimą ir gyvenimo prasmès (iš)gryninimą, priklauso nuo auklëjimo šeimoje patirčių. Tyrimo atskleistą neigiamą sąsają tarp valdingo auklejjimo ir dvasingumo tikriausiai galima paaiškinti tuo, kad tokị auklejjimo stilių taikantys tèvai dẻl savo nenoro atsižvelgti ị vaiko reikmes dažnai sukuria vaikui vidinị nepatogumą, o remiantis M. H. Pieper ir W. J. Pieper'io (2013) intrapsichinio humanizmo teorija, mažamečiai vaikai bet kokị elgesị su jais pasąmoningai priima kaip tobulą globą ir vẻliau siekia kuo daugiau patirti to, ką jau yra patyrę. Nepakankamą vidinès geros būsenos lygi jie pasąmoningai tapatina su vidine laime, nesuvokdami, kad tai yra iškreiptas jų vidinis optimizmas. Todèl suaugystejje tokie vaikai negali išsiveržti iš šios jų dvasią ribojančios būsenos ir jiems būna sunku siekti dvasinès brandos.

Remiantis intrapsichinio humanizmo teorija, galima aiškinti ir nereikšmingą trečiojo - leidžiančiojo auklejjimo stiliaus sąsają su bendru dvasingumu: panašu, kad ši stilių taikantys tėvai instinktyviai siekia užtikrinti pozityvų savo vaiko nusiteikimą jų atžvilgiu, stengdamiesi numaldyti savo pačių vidinị nelaimingumą. Dera pridurti, kad tokiems tėvams neretai tenka beveik visai atsisakyti savo, kaip motinos ar tėvo, vaidmens, kad nesukeltų savo vaikui pykčio, nes nustatinėti vaikui ribas jiems atrodo pernelyg rizikinga. Šiame modelyje vėlgi vaikui padaroma žala, jo poreikiai netinkamai tenkinami, nes tèvai nèra pakankamai brandūs ir nesugeba reguliuoti jo vystymosi.

Apskritai galima teigti, kad ir valdingiems, ir leidžiantiems tėvams, kuriems patiems būdingas vidinis nelaimingumas, džiaugsmingų santykių su vaikais perspektyva gali pasirodyti bauginanti, todèl tokių santykių jie pasąmoningai stengiasi išvengti. F. Cuzzocrea su kolegomis (2015) atliko tyrimą ir nustatè, kad disfunkciniai valdingasis ir leidžiantysis auklëjimo stiliai teigiamai koreliuoja su tèvų aleksitimija, kuri apibrèžiama kaip emocijų suvokimo, apdorojimo ir raiškos sutrikimas, kai negebama atpažinti ir apibūdinti savo bei kitų žmonių emocijų. Aleksitimiški valdingi tėvai dèl savo negebėjimo užmegzti abi puses tenkinančius santykius su vaiku dažnai pasitelkia dar ir psichologinę kontrolę, nes negebėdami tinkamai reaguoti i vaiko emocijas, jie sukuria emocini atstumą, i kuri patys reaguoja kaip i santykiui su vaiku kylančią grèsmę, todèl psichologinės kontrolès taktikos šiems 
tèvams tenka imtis tam, kad prisirištų vaiką fiziškai ir emociškai (Cuzzocrea ir kt., 2015).

Todèl iš visų auklëjimo stilių tinkamas yra tik autoritetingasis ${ }^{7}$. Mūsų tyrimo rezultatai atskleide, kad tik jis teigiamai ir reikšmingai koreliuoja su dvasingumu ir paskiromis jo dimensijomis bei yra statistiškai reikšmingas teigiamas dvasingumo prediktorius. Galima teigti, kad asmens santykio su aukštesne jẻga kokybè bus panaši ị santykio su tèvais kokybę, nes augdamas žmogus internalizuoja jam svarbius santykius, kurie tampa jo vidiniais dariniais, o šie savo ruožtu yra išveikiami ir iš naujo išgyvenami išoriniuose santykiuose. Šiame kontekste tampa svarbu ne tiek individo susiformuotas jam svarbių žmonių ir aukštesnès jègos ịvaizdis, kiek internalizuotų santykių su jais matricos: jų prigimtis ne tik intrapsichinè, bet ir tarpasmeninè.

Mūsų tyrimo nustatytą moteriškos lyties svarbą, prognozuojant dvasingumą, patvirtina ir kitų tyrimų rezultatai (žr. Kirk ir kt., 1999). Gali būti, kad merginos surinko aukštesnius dvasingumo ịverčius dèl didesnio jų organizmuose esančio hormono estrogeno kiekio, kuris lemia ne tik domèjimąsi kitais žmonėmis ir jautresnį bendravimą su jais, polinkị puoselèti artumą, bet ir gebèjimą suderinti priešybes, sutelkti dèmesị ị platesnes sampratas, apibendrinti ir atlikti sintezę bei toleruoti dviprasmybes - visa tai tampa ịmanu todèl, kad asmenys, įsčiose labiau paveikti estrogeno, tarp smegenų pusrutulių turi daugiau jungčių (Baron-Cohen, 2003; Fisher, 2010).

Svarbu ir tai, kad estrogeno kiekis organizme teigiamai koreliuoja su neuromediatoriaus serotonino kiekiu: jei stinga estrogeno, sutrinka ir pastarojo gamyba, nes estrogenas stimuliuoja smegenyse serotonino receptorius (žr. Bope, Kellerman, 2016), o didesnis serotonino aktyvumas lemia polinkị ị transcendavimą ir religingumą (Borg ir kt., 2003). Čia galima įžvelgti sąsajas su save aktualizuojantiems žmonèms būdingomis savybèmis, visų pirma tuo, kad su serotonino aktyvumu susijęs polinkis ị mistines patirtis, arba viršūnių išgyvenimus.

Tyrimas atskleide ir tai, kad amžius reikšmingai lemia dvasingumą. Toks rezultatas patvirtina žmogaus psichologinę ir dvasinę brandą tiriančių mokslininkų įžvalgas: kai kurie jų neabejoja, kad visą gyvenimą trunkanti asmenybės branda yra normatyvus reiškinys, bent jau fiziškai sveikiems asmenims. G. Vaillant'o (1995) teigimu, su amžiumi didèja išmintis ir mažèja nebrandžiu gynybos mechanizmų taikymas. E. Midlarsky ir E. Kahana (1994) teigia, kad su amžiumi žmonès tampa vis altruistiškesni ir labiau prosocialūs, o ir pats A. Maslow'as $(1993,2009)$ savo

Autoritetingi tèvai myli savo vaiką išmintingai ir taiko tai, ką M. H. Pieper ir W. J. Pieper'is (2013) vadina meilingu reguliavimu. Meilingą reguliavimą minèti autoriai apibūdina kaip santyki su vaiku, kuriuo tèvai padeda jam suvokti, kad vidinis laimès jausmas kyla iš meilès ir žinojimo, jog esi meilès vertas, mylimas, o ne siekiant patenkinti konkrečius poreikius (šis modelis būdingas valdingajam auklèjimui). 


\section{Simona Kontrimienè}

darbuose pagrindè prielaidą, kad asmenybė bręsta visą gyvenimą, tenkindama vis daugiau savo poreikių.

Šias tendencijas atskleidè ir kiti moksliniai tyrimai, pavyzdžiui, nustatyta, kad vyresnių nei $36 \mathrm{~m}$. amžiaus žmonių motyvai ir poreikiai aukštesni nei jaunesnių žmonių (Reiss, Havercamp, 2005), be to, vyresni nei $36 \mathrm{~m}$. amžiaus asmenys yra labiau save aktualizavę (Ivtzan ir kt., 2013). C. G. Jung'as (1933) rašè, kad jaunam žmogui pernelyg užsiimti savo asmenybe yra vos ne nuodèmė arba bent jau pavojinga, o senstančiajam daugiau dèmesio skirti savo savasčiai - pareiga ir būtinybè.

Dar vieną mūsų tyrimo radini - tai, kad ir merginų, ir vaikinų saugusis prieraišumas suaugystèje lemia jų dvasingumą, galima paaiškinti tuo, kad prieraišumo fone tarsi surašomi tarpasmeninių santykių scenarijai, kurie lemia asmenines nuostatas ir pasaulio suvokimą. Prieraišumo teorijos tyrimai atskleidžia, kad saugusis prieraišumas sudaro pagrindą visų mūsų modelyje išskiriamų dvasingumo dedamujų - savęs aktualizavimo, transcendavimo ir gyvenimo prasmès (iš)gryninimo - formavimuisi, nes toks prieraišumas formuoja teigiamą savivaizdị ir Kito įvaizdi, didina pasitikèjimą Kitu bei norą užmegzti su Juo artimą santykį, taip pat smalsumą ir atvirumą patyrimui, gebejjimą peržengti save, išeiti iš savo ,patogumo zonos" (arba save transcenduoti) (žr. Shaver, Hazan, 1993).

Saugiojo prieraišumo sąsajas su dvasingumu patvirtina ir kitų tyrimų rezultatai (žr. Hiebler-Ragger ir kt., 2016). Jas galima paaiškinti sudètingu reakcijų i aplinkinị pasaulį mechanizmu: asmenys, kuriems būdingas saugusis prieraišumas suaugystėje, geba susidoroti su neigiamomis patirtimis pasitelkę mentalines anksčiau patirtos rūpos reprezentacijas (tropus) (Mikulincer, Shaver, 2004), jų giliai išgyvenamas saugumas išlaisvina energiją, kurios reikia tam, kad būtų galima atsigręžti ị kitus, pripažinti ne tik savo, bet ir kitu troškimus, poreikius bei siekti autonomijos, kartu ir susietumo (Flores, 2004).

Tuo metu vengiančiojo tipo prieraišumas dažnai lemia neigiamą požiūrị i Kitą ir polinkị vengti artumo bei susietumo, o iš nerimastingo prieraišumo kyla neigiamas požiūris ị save ir polinkis nerimauti dèl to, kad būsi paliktas ateityje. Kita vertus, asmenys, kuriems nebūdingas vengiančiojo tipo prieraišumas, susiformuoja teigiamą požiūrị i Kitą, dėl to jų elgesio su Kitu modelis taip pat teigiamas jiems nuoširdžiai rūpi Kito gerovè. Tokią prielaidą pagrindžia J. Belsky’io (1997) evoliucinis saugaus prieraišumo išdavų aiškinimas: jei kiti žmonės priimami kaip geranoriški ir patikimi, jie ima rūpèti ir kyla noras užtikrinti jų gerovę.

Apibendrinant mūsų tyrimo rezultatus galima teigti, kad asmenybès raidos trajektoriją didele dalimi lemiančios auklèjimo šeimoje patirtys gali tarnauti ir kaip dvasingumo etiologijos veiksniai, nes santykio su tèvais kokybė sukuria kontekstą, kuriame skatinami arba slopinami asmens dvasiniai siekiai ir vertybės. Žmogaus dvasinė raida dažnai vyksta pagal principą „kaip su tèvais, taip ir su Dievu“, taigi 
asmens suformuota Dievo samprata gali būti tėvams jaučiamų jausmų projekcija. Tačiau teigti, kad auklejjimo šeimoje patirtys labiausiai lemia žmogaus dvasinio vystymosi trajektoriją būtų tolygu redukcionistinès ad hoc raidos hipotezès prièmimui, tai patvirtina mūsų sudaryti hierarchinès regresijos modeliai, pagal kuriuos tyrime analizuoti auklejjimo šeimoje patirtis atskleidžiantys kintamieji paaiškina tik nedidelę dvasingumo kintamojo dispersijos dalị.

\section{Literatūra}

Ainsworth, M. D. S., Blehar, M. C., Waters, E., Wall, S. (1978). Patterns of Attachment: A Psychological Study of the Strange Situation. Hillsdale, NJ: Erlbaum.

Ainsworth, M. D. S. (1989). Attachments beyond infancy. American Psychologist, Vol. 44, p. 709-716.

Anthony, M. (2006). Putting Childrens' Spirituality in Perspective. In M. Anthony (ed.). Perspectives on Children's Spiritual Formation: Four Views. USA: Broadman \& Holman Publishers, p. 1-44.

Aramavičiūtè, V. (2005). Auklëjimas ir dvasinè asmenybès branda. Vilnius: Gimtasis žodis.

Aramavičiūtè, V. (2010). Vyresniųų mokinių dvasingumas globalizacijos iššūkių kontekste. Lietuviu kataliku mokslų akademijos metraštis, Nr. 33, p. 193-211.

Armsden, G. C., Greenberg, M. T. (1987). The Inventory of Parent and Peer Attachment: Relationships to WellBeing in Adolescence. Journal of Youth and Adolescence, Vol. 16, p. 427-454.

Barber, B. K. (1996). Parental psychological control: Revisiting a neglected construct. Child Development, Vol. 67, p. 3296-3319.

Barber, B. K., Maughan, S. L., Olsen, J. A. (2005). Patterns of parenting across adolescence. In J. G. Smetana (ed.). New directions for child development: Changes in parental authority during adolescence. San Francisco, Jossey-Bass, p. 61-69.

Baron-Cohen, S. (2003). The Essential Difference: The Truth about the Male and Female Brain. New York: Basic Books.

Bartholomew, K. (1990). Avoidance of intimacy: An attachment perspective. Journal of Social and Personal Relationships, Vol. 7, p. 147-178.

Bartholomew, K., Horowitz, L. M. (1991). Attachment styles among young adults: A test of a four category model. Journal of Personality and Social Psychology, Vol. 61, p. 226-244.

Bartkowski, J. P., Xu, X. H., Levin, M. L. (2008). Religion and child development: Evidence from the early childhood longitudinal study. Social Science Research, Vol. 37, p. 18-36.

Baumbach, K., Forward, G. L., Hart, D. (2006). Communication and Parental Influence on Late Adolescent Spirituality. Journal of Communication and Religion, Vol. 29, p. 394-420.

Baumrind, D. (1971). Current patterns of parental authority. Developmental Psychology Monographs, Vol. 4, p. 1-103.

Baumrind, D. (2005). Patterns of Parental Authority and Adolescent Autonomy. New Directions for Child and Adolescent Development, Vol. 108, p. 61-69.

Baumrind, D. (2013). The History and Current State of Authoritative Parenting Research. In R. E. Larzelere, A. Sheffield Morris, A. W. Harrist (eds.). Authoritative Parenting: Synthesizing Nurturance and Discipline for Optimal Child Development. Washington, DC: APA, p. 11-34.

Belsky, J. (1997). Attachment, mating, and parenting - An evolutionary perspective. Human Nature, Vol. 8, p. 361381 .

Bitinas, B. (2000). Ugdymo filosofija. Vadovėlis. Vilnius: Enciklopedija.

Bope, E. T., Kellerman, R. D. (2016). Conn's Current Therapy. Philadelphia: Elsevier Inc.

Borg, J., Andree, B., Soderstrom, H., Farde, L. (2003). The Serotonin System and Spiritual Experiences. American Journal of Psychiatry, Vol. 160, p. 1965-1969.

Bowlby, J. (1973). Attachment and loss. Vol. 2. Separation, anxiety and anger. New York: Basic Books.

Bowlby, J. (1982). Attachment and loss. Vol. 1. Attachment (2nd ed.). New York: Basic Books.

Brelsford, G. M., Mahoney, A. (2008). Spiritual disclosure between older adolescents and their mothers. Journal of Family Psychology, Vol. 22, p. 62-70.

Buri, J. R. (1991). Parental Authority Questionnaire (PAQ). Journal of Personality Assessment, Vol. 57, p. 110-119. 


\section{Simona Kontrimienè}

Cuzzocrea, F., Barberis, N., Costa, S., Larcan, R. (2015). Relationship Between Alexithymia, Parenting Style, And Parental Control. Psychological Reports, Vol. 117, p. 580-596.

Damasio, A. (2003). Looking for Spinoza: Joy, Sorrow, and the Feeling Brain. Orlando: Harcourt.

Darling, N., Steinberg, L. (1993). Parenting style as context: an integrative model. Psychological Bulletin, Vol. 113, p. 487-496.

Dominguez, M., Carton, J. S. (1997). The Relationship Between Self-Actualization and Parenting Style. Journal of Social Behavior and Personality, Vol. 12, p. 1093-1100.

Elkins, D. N., Hedstrom, L. J., Hughes, L. L., Leaf, J. A., Saunders, C. (1988). Toward a Humanistic-Phenomenological Spirituality: Definition, Description, and Measurement. Journal of Humanistic Psychology, Vol. 28, p. 5-18.

Elkins, D. N. (1998). Beyond Religion: A Personal Program for Building a Spiritual Life Outside the Walls of Traditional Religion. Wheaton, Illinois: Quest Books.

Elkins, D. N. (2015). Beyond Religion: Toward a Humanistic Spirituality. In K. J. Schneider, J. F. T. Bugental, J. F. Pierson (eds.). The Handbook of Humanistic Psychology. $2^{\text {nd }}$ ed. California: Sage Publications, Inc., p. 681692.

Emmons, R. A. (1999). The psychology of ultimate concern: Motivation and spirituality in personality. New York: Guilford Press.

Fisher, H. (2010). Kodèl jis? Kodèl ji? Kaip sužinoti savo asmenybès tipa ir surasti tikrają meilę. Vilnius: Baltos lankos.

Flores, P. J. (2004). Addiction as an Attachment Disorder. Plymouth: Jason Aronson.

Frielingsdorf, K. (2003). Demoniški Dievo ịvaizdžiai. Vilnius: Katalikų pasaulis.

Gilliam, B., Franklin, J. T. (2004). The strength of vulnerability. Reclaiming Children and Youth, Vol. 13, p. 144 148.

Gold, J. M. (2013). Spirituality and Self-Actualization: Considerations for 21st-century Counselors. Joumal of Humanistic Counseling, Vol. 52, p. 223-234.

Groome, T. (2001). Educating for Life: A Spiritual Vision for Every Teacher and Parent. New York: Crossroad Publishing Company.

Hardy, S. A., Carlo, G. (2005). Religiosity and prosocial behaviors in adolescence: The mediating role of prosocial values. Journal of Moral Education, Vol. 34, p. 231-249.

Hay, D., Nye, R. (2006). The Spirit of the Child. London: Jessica Kingsley Publishers.

Hiebler-Ragger, M., Falthansl-Scheinecker, J., Birnhuber, G., Fink, A., Unterrainer, H. F. (2016). Facets of Spirituality Diminish the Positive Relationship between Insecure Attachment and Mood Pathology in Young Adults. PLOS One, Vol. 11, p. 1-6.

Hill, P. C., Pargament, K. I., Hood, R. W., McCullough, M. E., Swyers, J. P., Larson, D. B., Zinnbauer, B. J. (2000). Conceptualizing religion and spirituality: Points of commonality, points of departure. Journal for the Theory of Social Behaviour, Vol. 30, p. 51-77.

Hood, R. W., Jr., Hill, P. C., Spilka, B. (2009). The psychology of religion: An empirical approach, 4th ed. New York: The Guilford Press.

Humanist Manifestos I, II and III. (2003). Washington, DC: American Humanist Association. Prieiga internete: http://www.onthewing.org/user/Apo_Humanist\%20Manifesto\%20I-II-III.pdf.

Jovaiša, L. (2011). Edukologija. T. 1. Vilnius: Agora.

Jung, C. G. (1933). Modern Man in Search of a Soul. New York: Harcourt, Brace, World.

Lawler-Row, K. A. (2010). Forgiveness as a mediator of the religiosity-health relationship. Psychology of Religion and Spirituality, Vol. 2, p. 1-6.

Kalenda, Č. (1996). Altruizmas. Vilnius: Vilniaus pedagoginis universitetas.

Kapuscinski, A. N., Masters, K. S. (2010). The Current Status of Measures of Spirituality. Psychology of Religion and Spirituality, Vol. 2, p. 191-205.

Kirk, K. M., Eaves, L. J., Martin, N. G. (1999). Self-transcendence as a measure of spirituality in a sample of older Australian twins. Twin Res, Vol. 2, p. 81-87.

Koenig, L. B., McGue, M., Krueger, R. F., Bouchard, Jr. T. J. (2005). Genetic and Environmental Influences on Religiousness: Findings for Retrospective and Current Religiousness Ratings. Journal of Personality, Vol. 73, p. 471-488.

Kontrimiené, S. (2018). Dvasingumo vertinimas: humanistinio dvasingumo aprašo kūrimas ir validavimas. Tiltai, Vol. 81, p. 1-23. 


\section{HUMANISTINIO DVASINGUMO RYŠYS SU AUKLĖJIMO ŠEIMOJE PATIRTIMIS}

Kontrimienè, S. (2019). Assessing Spirituality as the Ultimate End: Development and Validation of the Humanistic Spirituality Inventory. Journal of Humanistic Psychology, article first published online. Retrieved from: https://journals.sagepub.com/doi/abs/10.1177/0022167819850678

MacKinlay, E. (2010). Ageing and Spirituality Across Faiths and Cultures. London: Jessica Kingsley Publishers.

Martišauskienė, E. (2004). Paauglių dvasingumas kaip pedagoginis reiškinys. Vilnius: VPU.

Martišauskienė, E. (2008). Šviesos pedagogikos kontūrai: dvasingumo ugdymo pamatai. Vilnius: VPU.

Maslow, A. H. (1993). The farther reaches of human nature. New York: Penguin / Arkana.

Maslow, A. H. (1999). Toward a psychology of being. $3^{\text {rd }}$ ed. New York: Wiley.

Maslow, A. (2009). Motyvacija ir asmenybe. Vilnius: Apostrofa.

Midlarsky, E., Kahana, E. (1994). Altruism in Later Life. Thousand Oaks, CA: Sage.

Mikulincer, M., Shaver, P. R. (2004). Security-Based Self-Representations in Adulthood: Contents and Processes. In W. S. Rholes, J. A. Simpson (eds.). Adult attachment: Theory, research, and clinical implications. New York: Guilford Press, p. 159-195.

Murray-Swank, A., Mahoney, A., Pargament, K. I. (2006). Sanctification of parenting: Influences on corporal punishment and warmth by liberal and conservative Christian mothers. International Journal of the Psychology of Religion, Vol. 16, p. 271-287.

Otway, L. J., Carnelley, K. B. (2013). Exploring the associations between adult attachment security and selfactualization and self-transcendence. Self and Identity, Vol. 12, p. 217-230.

Pargament, K. I. (2001). The psychology of religion and coping. New York: Guilford Press.

Pieper, M. H., Pieper, W. H. (2013). Išmintinga meilé: jautrumu paremta drausmés alternatyva, padésianti jums tapti geresniais tévais, o jūsų vaikams užaugti visaverčiais žmonèmis. Vilnius: Katalikų pasaulio leidiniai.

Reiss, S., Havercamp, S. M. (2005). Motivation in a developmental context: A new method for studying selfactualization. Journal of Humanistic Psychology, Vol. 45, p. 41-53.

Rogers, C. R. (2005). Apie tapima asmeniu. Vilnius: Atviros Lietuvos knyga.

Schneider, K. J., Bugental, J. F. T., Pierson, J. F. (2015). Introduction. In K. J. Schneider, J. F. T. Bugental, J. F. Pierson (eds.). The Handbook of Humanistic Psychology, 2nd ed. California: Sage Publications, Inc., p. xix-xvi.

Sheldrake, P. (2007). A Brief History of Spirituality. Australia: Blackwell Publishing.

Silk, J. S., Morris, A. S., Kanaya, T., Steinberg, L. (2003). Psychological control and autonomy granting: Opposite ends of a continuum or distinct constructs? Journal of Research on Adolescence, Vol. 13, p. 113-128.

Snyder, C. R., Lopez, S. J. (eds.). (2002). Handbook of Positive Psychology. New York: Oxford University Press, Inc.

Soenens, B., Vansteenkiste, M., Duriez, B., Goossens, L. (2005). In search of the sources of psychologically controlling parenting: the role of parental separation anxiety and parental maladaptive perfectionism. Journal of Research on Adolescence, Vol. 16, p. 539-559.

Vaillant, G. (1995). Adaptation to life. London: Harvard University Press.

Waaijman, K. (2002). Spirituality: forms, foundations, methods. Leuven: Peeters.

\section{RELATIONSHIP BETWEEN HUMANISTIC SPIRITUALITY AND PARENTING EXPERIENCES}

\section{Simona Kontrimienè}

\section{Summary}

Spirituality is a complex multidimensional phenomenon which does not yield itself to a universal conceptualisation, though it is possible to distinguish common variables in the views of this construct from its diverse definitions. The proposed Humanistic Spirituality Model best reflects the secularised reality of today and captures the essential dimensions of spirituality through three components: 1) self- 
actualisation, which implies a mature perception of reality, spontaneity, creativity, peak experiences, personal growth, detachment, Gemeinschafsgefühl and profound interpersonal relations; (2) transcendence, which implies belief in the Higher Power, self-transcendence and a holistic approach to Being; and (3) ultimate meaning in life, which presupposes awareness of faith-inspired directedness and ontological significance of life. The model served as the basis for the development of the Humanistic Spirituality Inventory, a 40-item measure which contains three scales corresponding to the three model components and has good psychometric properties, i.e. adequate content and construct validity as well as satisfactory internal consistency and testretest reliability (Kontrimienè, 2019).

The current study $(N=514)$ explores the relationship between humanistic spirituality and parenting experiences as its etiological determinants defined herein as parenting styles, parental psychological and behavioural control and parental and adult attachment styles in a sample of students drawn from five Lithuanian universities. The authoritative parenting style (see Baumrind, 2005) is described as controlling but flexible, it presupposes parental acceptance and responsiveness as well as support for child's age-appropriate independence. Authoritarian parenting implies low responsiveness, low nurturance, the use of detrimental forms of power assertion, love withdrawal and imposition of many rules to gain compliance. Lastly, permissive parenting is viewed as an accepting, responsive but lax pattern of parenting in which parents abdicate their parental authority, make relatively few demands and rarely exert firm control over their child's behaviour.

Parental behavioural control refers to parental regulation of child's behaviours and implies parental knowledge and monitoring (Barber, 2005). Parental psychological control constrains, invalidates and manipulates the child's psychological and emotional experience and includes such dimensions as constraining verbal expressions, invalidating feelings, personal attack, guilt induction and love withdrawal (Barber, 1996).

Attachment styles (as proposed in Ainsworth's (1989) theory) capture three distinct patterns referred to as secure, insecure-avoidant and insecure-ambivalent. The secure style develops in children who use the attachment figure as a safe base in times of distress. The insecure avoidant style characterises children who do not orientate to the attachment figure. The insecure ambivalent style refers to children who adopt an ambivalent behavioural style towards the attachment figure, exhibit clingy and dependent behaviour but tend to be rejecting of the attachment figure in an interaction. These three patterns of attachment are decisive in the development of internal working models (or schemas) which govern behaviour in adulthood.

The secure adult attachment style (Bartholomew, Horowitz, 1991) presupposes a positive perception of the self and a positive regard of others, which often leads 
to the creation of mature trusting relationships. The ambivalent style is associated with a negative perception of the self and a positive perception of others, which increases the likelihood of preoccupation with relationships. The dismissing-avoidant style entails a positive perception of the self and a negative perception of others, for which reason close relationships are avoided. Finally, the fearful-avoidant style presupposes a negative perception of both the self and others and may result in an urge to seek proximity but remain detached from significant others to protect emotions.

The main findings of our study suggest that of the three parenting styles, only the authoritative style is a significant positive predictor of spirituality, though secure attachment in adulthood and the two demographic variables, age and female gender, serve as even more salient predictors. Both parents' behavioural and psychological control forms do not predict humanistic spirituality, whereas secure attachment to the mother furthers spirituality indirectly as it is a significant predictor of one of the most important determinants of spirituality, secure attachment in adulthood. These results suggest that experiences of parenting may serve as important factors in the etiology of spirituality such that spiritual development takes place in accordance with the principle "as with parents, so with God", whereby the concept of God formed by a person may be a projection of feelings they have for their parents.

Simona Kontrimienė - lektorè, daktarè (socialiniai mokslai - edukologija - 07S), Vilniaus universiteto Filologijos fakulteto Užsienio kalbų institutas.

Moksliniai interesai: dvasingumas, auklèjimas šeimoje, psicholingvistika, meilès fenomenologija. Adresas: Universiteto g. 5, LT-01513 Vilnius.

Tel. +37061652088.

El. paštas: simona.kontrimiene@flf.vu.lt

Simona Kontrimienè - lecturer, doctor of Social Sciences (Education - 07S), Institute of Foreign Languages, Faculty of Philology, Vilnius University.

Scientific interests: spirituality, parenting, psycholinguistics, phenomenology of love.

Address: Universiteto Str. 5, LT-01513 Vilnius.

Phone: +37061652088.

E-mail: simona.kontrimiene@flf.vu.lt 